\title{
EXPERIMENTAL ANALYSIS OF THERMAL STRATIFICATION IN A HEAT STORAGE TANK USING STRATIFICATION PIPE
}

\section{TERMISKĀ STRATIFIKĀCIJA AR STRATIFIKĀCIJAS CAURULI APRĪKOTĀ SILTUMA AKUMULĀCIJAS TVERTNĒ. EKSPERIMENTĀLAIS PĒTĪJUMS}

\author{
A. Boloṇina, M.sc. \\ Institute of Energy Systems and Environment, Riga Technical University \\ 1, Kronvalda, LV-1010, Riga, Latvia \\ Phone: +37126465373 \\ e-mail: alona.bolonina@rtu.lv \\ C. Rochas, Dr.sc.ing. \\ Institute of Environment and Energy Systems, Faculty of Energy and Electrical Engineering, Riga Technical University \\ Address: Kronvalda blvd. 1, Riga, LV 1010, Latvia \\ Phone: 37167089923,37167089908 , \\ Fax: 37167089908 \\ e-mail: claudio.rochas@rtu.lv \\ D. Blumberga, Dr.habil.sc.ing., professor \\ Institute of Environment and Energy Systems, Faculty of Energy and Electrical Engineering, Riga Technical University \\ Address: Kronvalda blvd. 1, Riga, LV 1010, Latvia \\ Phone: 37167089923,37167089908 , \\ Fax: 37167089908 \\ e-mail: Dagnija.blumberga@rrtu.lv
}


Keywords: exergy, heat storage, heat storage tanks, stratification pipe, thermal stratification

\section{Introduction}

The importance of developing improved storage devices is a key aspect of the thermal optimisation of many energy systems that are characterized by the delay between energy production and consumption. Good performance of the storage devices can mean a considerable increase in the overall efficiency of the installation.

Good thermal properties of water and its low cost make sensible heat storage tank of liquid water the most traditional and extended equipment of storing [4].

Heat storage efficiency can be considerably increased by achieving good thermal stratification inside the storage tank.

Thermal stratification is a natural process which occurs due to changes of water density at different temperatures. Due to its higher weight, cold water remains at the bottom of the tank while hot water flows to the top part.

Rigid stratification pipes, which are vertically installed inside a heat storage tank, are usually made of polymers with low thermal conductivity to prevent vertical heat transfer. Stratifiers have a number of holes with nonreturn valves, which allow avoiding water flows from tank to stratification pipe. The valve opens only in case when water temperatures inside and outside the pipe are similar (thereby the densities of water inside and outside the pipe are also similar). In that way inflow water is transported to the right layer of heat storage tank. Stratification pipes not only create good stratification inside the tank, but also provide high degree of stratification during every charge of the tank. One of the most efficient, widely used and available stratification pipes is a stratifier produced by German company SOLVIS Solar Systeme GmbH. These stratifiers are developed and adjusted mostly for solar combisystems, but it doesn't limit their use in other systems.

\section{Experimental equipment}

The experimental heat storage system was developed in Environmental monitoring laboratory. The system includes the following main equipment:

- Heat storage tank. The tank was made of organic glass to make the process visible;

- Stratification pipe;

- Inlet and outlet pipes. To minimize vertical flow turbulences the shielded pipes were used;

- Heating source. Heat was supplied by $25 \mathrm{~kW}$ pellet boiler and two insulated heat storage tanks. This system is flexible enough to ensure certain temperature needed for the experiment;

- Monitoring system. The monitoring system includes measuring equipment for inlet and outlet flow temperatures, temperature inside the tank at 15 levels, inlet and outlet flow rates $[6,7]$.

\section{Implemented experiments}

Fully mixed tank tests were held at four different flow rates (within the range 2-10 $1 / \mathrm{min}$ ). Before the beginning of the test heat storage tank had been charged with cold water of a constant temperature. The water inside the tank considered to be fully mixed. During the experiment the hot water at a certain temperature was charged through the stratifier and discharged through the shielded outlet at the bottom of the tank. The range of implemented tests is shown in Table 1. During the tests the similar amount of energy and volume of water was charged into the tank. 
Implemented fully mixed tank tests

\begin{tabular}{|c|c|c|c|}
\hline Implemented tests & Inlet temperature, ${ }^{\circ} \mathbf{C}$ & Flow rate, $\mathbf{l} / \mathbf{m i n}$ & $\begin{array}{c}\text { Approximate time } \\
\text { of a test, } \text { min }\end{array}$ \\
\hline Heating test $\left(10\right.$ to $\left.40^{\circ} \mathrm{C}\right)$ & $40 \pm 2$ & $2 \pm 0,5$ & 85 \\
\hline & $40 \pm 2$ & $6 \pm 0,5$ & 30 \\
\hline & $40 \pm 2$ & $10 \pm 0,5$ & 20 \\
\hline & $40 \pm 2$ & $14 \pm 0,5$ & 15 \\
\hline
\end{tabular}

Using the monitoring system all necessary data was registered with the interval of 5 seconds. To process all this data the Microsoft Excel Macro in Visual Basic was developed. The Macro has the following functions:

1. Processing monitoring data;

2. Developing temperature distribution for fully mixed and perfectly stratified tank using experimental data;

3. Calculating the momentum of energy of each layer for fully mixed, perfectly stratified and real temperature distribution;

4. Calculating the entropy for each layer;

5. Summarizing the results and calculating the mixing number for every minute of the test $[6$, 7].

\section{Parameters used to characterize thermal stratification}

Thermal stratification in heat storage tank can be characterized by different parameters as The Figure of Merit (FOM), thermocline thickness, Richardson number, charging and discharging efficiency, Peclet number, Reynolds number etc [1].

One of the most common parameters used to characterize thermal stratification, which was also used in the experimental research, is mixing number (MIX). This number is based on the energy and temperature distribution level in the tank and is determined by the moment of energy. MIX number perfectly displays the dynamics of stratification process. It decreases when there is increase of thermal stratification degree and is equal to zero in case of perfect stratification.

Although this parameter characterizes the changing thermodynamic profile of the tank, it is usable only in case of constant mass flow and geometry of the tank. Respectively, the MIX number can't be used to compare different charge and discharge strategies in the same thermal storage tank. That is why there was a need for other parameters to be analyzed. One of possibilities to describe thermal stratification investigated in the framework of this study is the exergy.
Different forms of energy have different quality, which represents their ability to promote energetic processes and to be transformed to other forms of energy. For example, the quality of heat depends on heat source temperature - the higher temperature, the greater part of energy can be transferred into mechanical work.

The Second Law of Thermodynamics helps to define the work, which can be performed by thermodynamic system in certain conditions if the process is reversible and the work performed in real conditions, i.e. in nonreversible process.

Accordingly to the common definition exergy is the maximum work capacity of the substance in reversible process with environment $[3,5]$.

The energy efficiency of a thermal storage system, the ratio of the energy recovered from storage to that originally input, is conventionally used to measure heat storage system performance. The energy efficiency, however, is an inadequate measure because it does not take into account all the considerations necessary in system evaluation. Exergy analysis is a thermodynamic analysis technique based on the Second Law of Thermodynamics which provides an alternative means of assessing and comparing heat storage systems rationally and meaningfully. In particular, exergy analysis yields efficiencies which provide a true measure of how nearly actual performance approaches the ideal, and identifies more clearly than energy analysis the causes and locations of thermodynamic losses [2].

Fully mixed and perfectly stratified storage tanks with similar average temperature contain similar amount of energy. However stratified tank contains the energy of higher potential, because the temperature in upper layer of the tank is considerably higher. Thermal mixing process is not reversible, that is why it causes energy quality losses.

\section{Experimental data analysis}

Measured temperature distribution in experimental heat storage tank showed that Solvis stratifier provides thermal stratification in all tested range of flow rates. The mixing number also reflected the dynamics of this 
process. Still these parameters cannot be used for developing equations to characterize certain system efficiency and comparative degree of thermal stratification. One of the tasks of the experiment was to define the optimum flow rate for Solvis stratifier to minimize heat losses due to thermal mixing and to build good stratification inside the tank. Therefore alternative parameters were investigated to perform system analysis.

From the heat consumer's point of view it is important to keep the temperature in the upper layers of the tank similar to incoming flow temperature. Keeping low temperature at the bottom of the tank is important as well. Therefore the indicators based on the changes of temperatures were used to characterize the efficiency of stratification device.

One of the advantages of thermal stratification, in particular in solar collector systems, is possibility to keep low temperature at the bottom of heat storage tank. In this way efficiency of solar collector can be increased. If bottom layer temperature increases, it means that thermal mixing processes occur inside the tank. Therefore one of parameters that possibly could describe operation of stratification device is the difference between $T_{1}$ (bottom layer temperature) at the end of test and $\mathrm{T}_{8}$ (the temperature of layer at height of $80 \mathrm{~cm}$ from the bottom of the tank) at the start of test. During each test the same amount of heat was charged into the tank. As inflow temperature was constant during all the experiments, similar volume (180 1) of high temperature water was charged (and discharged) as well. This volume forms a layer with height of $0,7 \mathrm{~m}$ inside the tank. In the conditions of perfect stratification the incoming hot water reaches upper layers of the tank. Lower layers are discharged from the tank. During the test initial cold water upper layers move down by the distance equal to inflowing water layer thickness. Consequently if perfect thermal stratification process occurs and there are no heat losses, the temperature of lower layer $\left(T_{1}\right)$ at the end of experiment is equal to the temperature $T_{8}$ at the start of the test. In this way the difference between the mentioned temperatures possibly could show how nearly to the perfect conditions the changes of cold water temperature are.

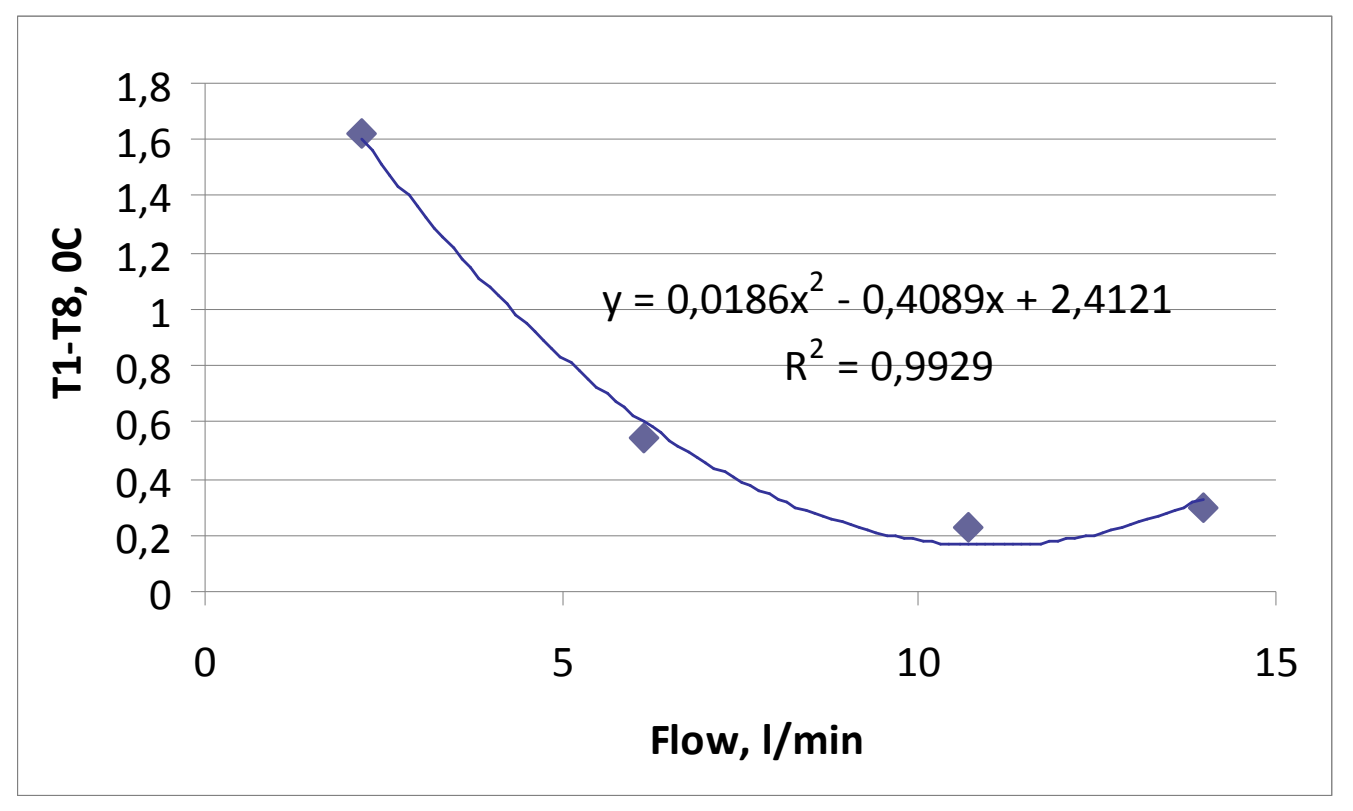

Fig.1. Cold water initial temperature changes

Relation between cold water temperature changes and flow rate shown in Fig. 1 is quadratic. $T_{1}-T_{8}$ reaches the highest value, which means lower stratifier efficiency, at flow rate $21 / \mathrm{min}$. It should be noted that the range of $\mathrm{dT}_{1-8}$ values is only $0-1,6{ }^{\circ} \mathrm{C}$. It means that flow rate impact on cold water temperature changes in absolute values is not sufficient. Still there is relation between these parameters.

One more parameter used to characterize the efficiency of Solvis stratification device within different flow rates is the difference between average inflow temperature and the average upper layer temperature during the test.
The efficiency of thermal storage depends on the amount of recovered heat. Although the amount of energy contained in heat storage does not depend on the degree of thermal stratification, lower temperature in the upper layers due to thermal mixing may cause necessity to supply more energy to satisfy consumer demand. During the tests with Solvis stratification device the differencies between upper layer temperatures in each experiment were observed although the inflow temperature was constant. The relation between $T_{\text {inflow }}-T_{13}$ is shown in Fig. 2 . 


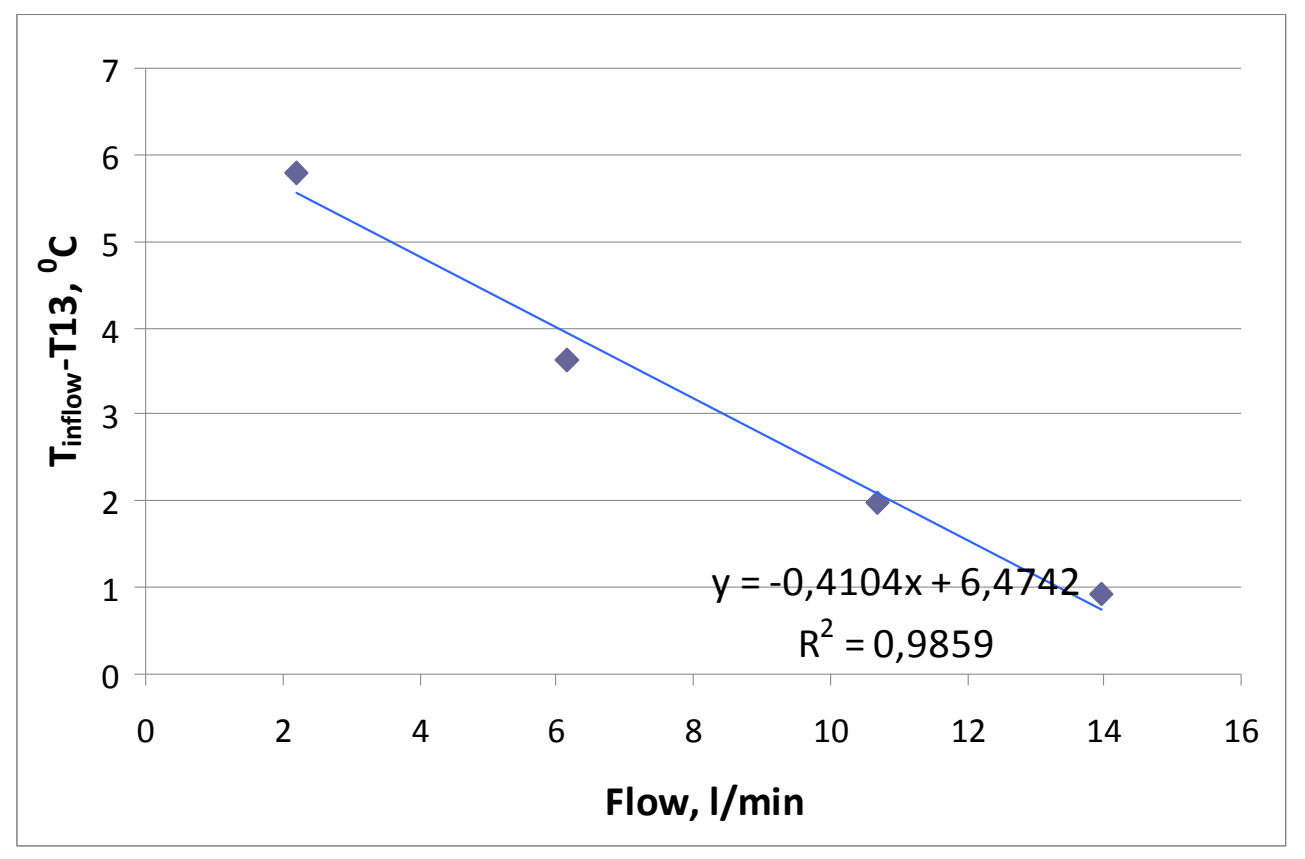

Fig.2. The difference between inflow and upper layer temperatures

There is a linear relation between the difference of average inflow temperature and upper layer temperature and the flow rate. At flow rate $21 / \mathrm{min} \mathrm{dT}_{\text {inflow-13 }}$ is the greatest $\left(5,8{ }^{\circ} \mathrm{C}\right)$ and great enough to impact negatively heat supply and storage system.

Although Solvis stratification pipe is made of polimer with low thermal conductivity (about $0,35 \mathrm{~W} / \mathrm{mK}$ ) at a very small flow rate water cooling inside the pipe occurs.

Using developed equations the optimum flow rate was calculated and its value is 10,991 . This value was defined as extremum point of the curve shown in Fig.1. Operation of Solvis stratifier within the tested flow rate range can be analyzed by defining the exergy of the tank. Stratified heat storage tank has greater exergy than fully mixed tank although the energy amount in both cases is the same. Rosen (2001) investigated equations to calculate the exergy of stratified heat storage tank as well as six mathematical models of temperature distribution inside the tank. The difference between exergy of stratified and fully mixed heat storage tank can be defined using the following equation:

$$
\Xi-\Xi_{m}=m c T_{0} \ln \left(T_{m} / T_{e}\right)
$$

$\Xi$ - actual exergy of the tank, $\mathrm{kJ}$;

$\Xi_{\mathrm{m}}-$ exergy of fully mixed tank, $\mathrm{kJ}$;

$\mathrm{m}$ - mass, kg;

$\mathrm{c}$ - heat capacity, $\mathrm{kJ} / \mathrm{kgK}$;

$\mathrm{T}_{0}$ - reference-environment temperature, $\mathrm{K}$;

$\mathrm{T}_{\mathrm{m}}$ - temperature of fully mixed water, $\mathrm{K}$;

$\mathrm{T}_{\mathrm{e}}$ - equivalent temperature of a mixed water that has the same exergy as stratified water, $\mathrm{K}$
There are six temperature distribution mathematical models: linear, stepped, continuous-linear, generallinear, basic three-zone and general three-zone [2].

For experimental data analysis the stepped temperature distribution model was used (Fig.3).

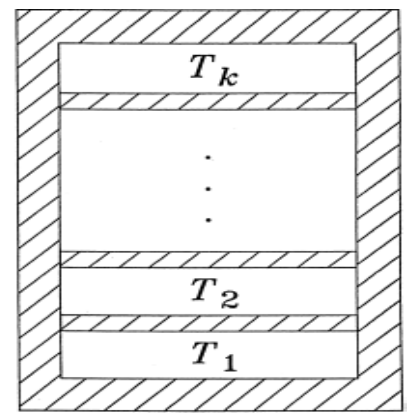

Fig.3. Stepped temperature distribution model

The stepped temperature distribution model consists of $\mathrm{k}$ horizontal zones, each of which has a constant temperature. Equivalent temperature $\left(\mathrm{T}_{\mathrm{e}}\right)$ using the stepped temperature distribution mathematical model can be described by the following equations:

$$
T_{e}=\prod_{j=1}^{k} T_{j}^{x_{j}}
$$

$T_{e}$ - equivalent temperature of a mixed water that has the same exergy as stratified water, $\mathrm{K}$;

$\mathrm{T}_{\mathrm{j}}$ - temperature of zone $\mathrm{j}, \mathrm{K}$;

$\mathrm{x}_{\mathrm{j}}$ - mass fraction of zone $\mathrm{j}$, which is constrained as follows: 


$$
x_{j}=\frac{m_{j}}{m} \quad \text { or } \quad x_{j}=\frac{h_{j}-h_{j-1}}{H}
$$

$\mathrm{m}$ - total mass, $\mathrm{kg}$;

$\mathrm{m}_{\mathrm{j}}-$ mass of zone $\mathrm{j}$;

$\mathrm{h}_{\mathrm{j}}$ - height of zone $\mathrm{j}, \mathrm{m}$;

$\mathrm{H}$ - total height of the tank, $\mathrm{m}$

The temperature of fully mixed water in case of stepped temperature distribuion can be expressed as follows:

$$
T_{m}=\sum_{j=1}^{k} x_{j} T_{j}
$$

$\mathrm{T}_{\mathrm{m}}$ - temperature of fully mixed water, $\mathrm{K}$;

$\mathrm{T}_{\mathrm{j}}$ - temperature of zone $\mathrm{j}, \mathrm{K}$;

$\mathrm{x}_{\mathrm{j}}$ - mass fraction of zone $\mathrm{j}$

The difference between exergy of actual and fully mixed tank using above-mentioned equations was defined for each test. Reference temperature $\left(\mathrm{T}_{0}\right)$ for all the tests was considered as cold water temperature inside the tank at the beginning of the test. The tank was devided into 13 zones with a constant temperature and height $0,1 \mathrm{~m}$ accordingly to the stepped temperature distribution model. The results of calculations are shown in

Fig.4.

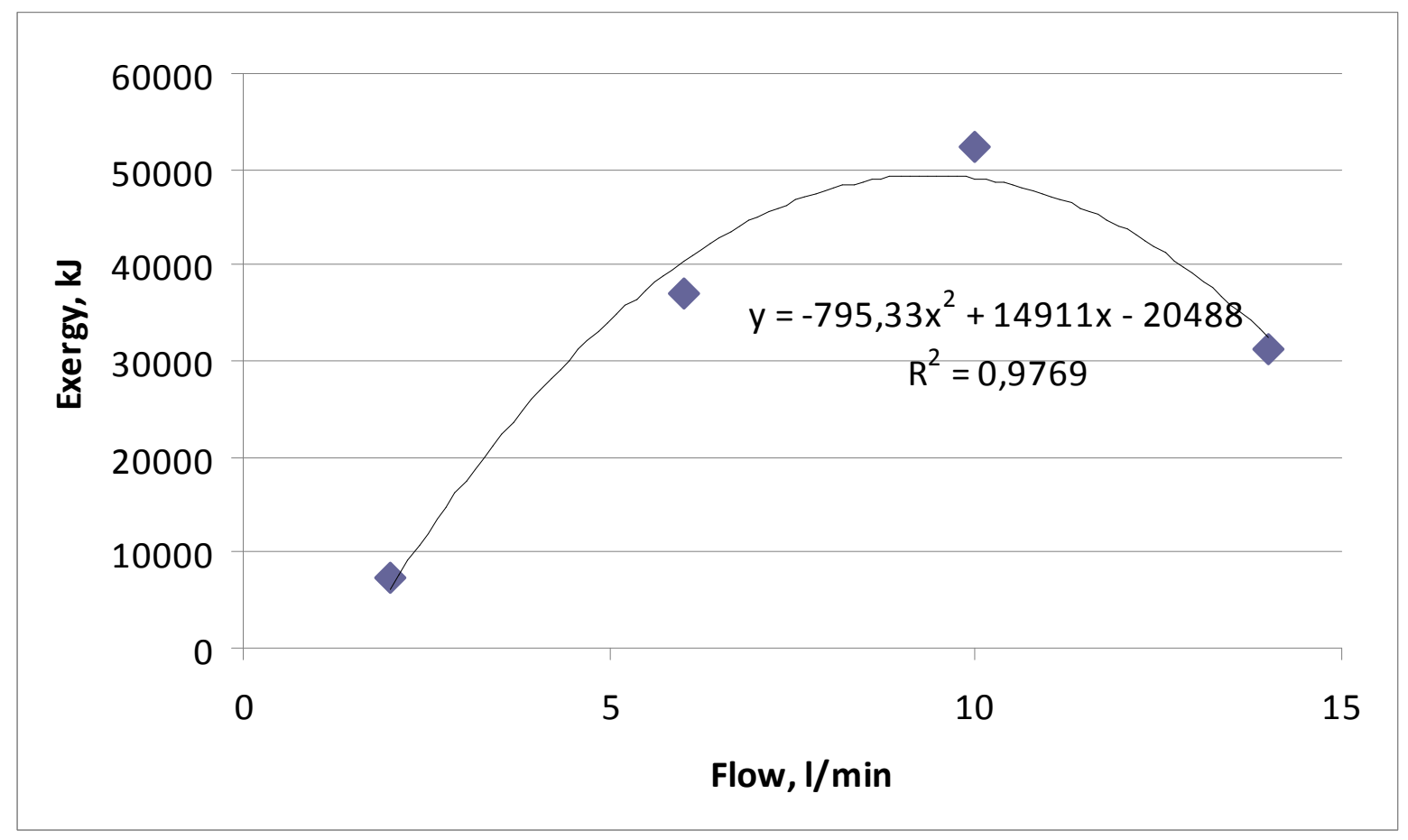

Fig.4. The difference between actual and fully mixed water exergy

The relation shown in Fig.3 confirms the results of previous calculations using the temperature differences (Fig.1). Both developed functions are parabolic and reflect a dicrease of stratification degree at higher and lower flows. In the extremum point of the function the value of flow rate is $9,37 \mathrm{l} / \mathrm{min}$. In this point the exergy has the greatest value, which means highest degree of thermal stratification and efficiency of stratification device.

\section{Conclusions}

Number of tests was made in the laboratory using experimental heat storage tank with rigid stratification device produced by company SOLVIS Solar Systeme
$\mathrm{GmbH}$. One of the aims of the experiments was to analyze the parameters used to characterize thermal stratification inside the tank and to define optimal flow for Solvis stratifier.

The analysis of the tests showed that the optimum flow rate which gives higher degree of thermal stratification and thereby higher exergy and temperature in the upper layers of the tank is between 9,37 and $10,991 / \mathrm{min}$. It has to be noted that the amount of experimental data is not sufficient to make well-grounded conclusions. To proceed investigation the wider range of flow rates and temperatures should be tested. Still described experimental investigation gives possibilities and directions for further research.

One of the conclusions of this work is that the exergy is a good parameter for characterizing thermal 
stratification and efficiency of thermal storage system. This parameter can be used for investigating equations of optimal inlet flow in the certain system.

\section{References}

1. Dimensionless parameters used to characterize water tank stratification / Castell A., Sole C., Medrano M., Castellon C., Cabeza L.F. // EuroSun 2006: International conference, 2006 July 27 - 30, Glasgow.

2. Rosen M. A. The exergy of stratified thermal energy storage // Solar energy. - Nr.71 (2001), 13 p.

3. Morris D. R., Steward F. R., Szargut J. Exergy analysis of thermal, chemical \& metallurgical processes. - Berlin: John Benjamins Publishing Co, 1988. - 400 p.

4. Rodriquez I., Consul R., Perez - Segarra, Soria M. Virtual prototyping of storage tanks by means of three-dimensional CFD and heat transfer numerical simulations // Solar energy. - Nr.77 (2004), 13 p.

5. Cieminšs R., Nagla J., Saveljevs P. Siltumtehnika. Rīga: Zvaigzne, 1967. - 454 lpp.

6. Boloņina A. Termiskā stratifikācija siltuma akumulācijas tvertnēs // maǵistra darbs. - Rīgas Tehniskā universitāte (2008)

7. Rochas C. Experimental analysis of solar combisystems. Optimization // phD. - thesis. - Riga Technical university (2008)
Siltuma akumulācijas tvertne ir svarīgs elements apkures sistēmās, kurās siltuma avots nespēj nodrošināt siltumenerğijas padevi atbilstoši patērētāja pieprasījumam.

Augstāku siltuma akumulācijas efektivitāti var sasniegt, nodrošinot termisko stratifikāciju siltuma akumulācijas tvertnē. Viena no efektīiākajām termiskās stratifikācijas pakāpes paaugstināšanas metodēm ir stratifikācijas caurules.

Rìgas Tehniskas universitātes Vides aizsardzības un siltuma sistèmu institūta Vides monitoringa laboratorijā izveidota eksperimentālā iekārta, kas tiek izmantota dažādu stratifikācijas ierīču pētījumiem pie dažādiem termodinamiskajiem un hidrauliskajiem darbības parametriem. Veicot eksperimentālo izpēti, analizèta Vācijas kompānijas SOLVIS Solar Systeme GmbH stratifikācijas caurules efektivitāte pie dažādiem siltumnesēja plūsmas parametriem ar mērķi noteikt optimālos siltuma akumulācijas sistēmas darbības parametrus, kas nodrošina visaugstāko termiskās stratifikācijas pakāpi.

Alona Bolonina, Claudio Rochas, Dagnija Blumberga, Experimental analysis of thermal stratification in a heat storage tank using stratification pipe

The heat storage tank is an important element in any heating system where the heat source is not able to provide heat accordingly to consumer demand (for example solar collector systems, solid fuel boilers etc).

Better heat storage efficiency can be achieved by providing good thermal stratification in the heat storage tanks. One of the best methods of increasing the degree of thermal stratification is the stratification pipes.

In the Environmental monitoring laboratory of the Institute of Energy Systems and Environment (Riga Technical University, an experimental heat storage system has been developed and used for testing and studying stratification devices under different thermodynamic and hydraulic conditions. The experimental study carried out on the efficiency of the stratification pipe produced by German company SOLVIS Solar Systeme GmbH under different flow parameters, has been analyzed. The main aim of the experimental study was to define optimal heating system operation parameters to achieve good performance of the stratification pipe and a high degree of thermal stratification in the heat storage tank.

Алена Болонина, Клаудио Роша, Дагния Блумберга, Экспериментальное исследование термической стратификации в баке-аккумуляторе тепла с использованием стратификатора

Бак-аккумулятор тепла - важный элемент отопительной системы, в которой источник тепловой энергии не обеспечивает подачу тепла, необходимого для потребителя.Повышение эффективности аккумуляичи возможно при использовании стратификации в баке-аккумуляторе. Одним из самых эффективных методов повымения степени стратификации является использование стратификачионных труб.

В лаборатории Мониторинга окружающей среды института Защиты окружающей среды и тепловых систем Рижского Технического университета создана экспериментальная установка для исследования стратификачионных приборов при различных термодинамических и гидравлических параметрах. В частности, проведено исследование
Aḷona Boloņina, Klaudio Rošā, Dagnija Blumberga, Termiskā stratifikācija siltuma akumulācijas tvertnē ar stratifikācijas cauruli. Eksperimentālais pētījums 
стратификационной трубы немецкой компании SOLVIS Solar Systeme GmbH с иелью определения оптимальных параметров работы аккумулирующей системы, чтобы обеспечить наивысшую степень стратификации. 